\title{
The Up-Coming Crisis and the Banking Sector in the Baltic States
}

\author{
Mejra Festić ${ }^{a}$, Sebastijan Repina $^{\mathrm{b}}$ and Alenka Kavkler ${ }^{c}$ \\ JEL-Classification: F47, G15, G21. \\ Keywords: cyclicality, non-performing loans, systemic risk, asset quality.
}

\section{Introduction}

In response to a global financial crisis in the 1980s and 1990s, national and international institutions began carefully monitoring the soundness of the financial system. As a result, the bulk of financial stability indicators have been greatly extended (MörtTinen et al., 2005): regulatory capital vs. risk-weighted assets; interest margins and non-interest expenses vs. gross income; a return on assets and a return on equity; the spread between the highest and lowest inter-bank rates; liquid asset to short-term liability ratios; liquid assets to total assets, as well as the cost-income ratio. Also included and usually used as indicators of financial stability and balance-sheet quality: credit relative to GDP; the net open position in foreign currency to capital; the geographical distribution of loans to total loans; the share of non-performing loans to total loans, as well as foreign-currencydenominated loans to total loans. According to the study of Schinasi (2005), common exposure to macroeconomic risk factors across banks is a source of systemic risk that influences the quality of a loan portfolio, which can be expressed as the non-performing loan to total gross loan (NPL) ratio. An increasing ratio may be a sign of deterioration in banking sector results. In theory, we would expect that the non-performing loans to total loans ratio would be procyclical within an economic cycle.

a Ph. D. Associated Prof., EPF - Faculty of Economics and Business, University of Maribor; EIPF - Economic Institute, Ljubljana. Slovenia.mejra.festic@uni-mb.si; mejra.festic@eipf.si; fax: 0038622508177.

b B.Sc., researcher, EIPF - Economic Institute, Ljubljana. Slovenia. sebastijan.repina@eipf.si. 0038612521688.

c Ph. D., Faculty of Economics and Business, University of Maribor, EIPF - Economic Institute, Ljubljana. Slovenia. alenka.kavkler@uni-mb.si; fax: 0038622508177. 
The Baltic States recorded the lowest share of non-performing loans among New EU Member States. The outlook for their banking sector results possibly reflects a favorable assessment of their economic growth. The increasing indebtedness of the private sector could become a cause for concern if the macroeconomic environment develops less favorably.

We analyzed the relationships between the non-performing loan ratio and macroeconomic/banking sector variables as a source of systemic risk, in order to assess the banking sector's vulnerability to bad loan performance on a macroeconomic level. In the second chapter (2.1) an overview of available literature and a theoretical background of the empirical analysis have been provided. A summary of the characteristics of the macro-economic environment and the banking sector in the Baltic States can be found in chapter 2.2. In chapter 2.3, the methodology of the empirical analysis and the empirical results are explained. The implications of the empirical analysis are revisited in the conclusion.

\section{Theoretical Background and Empirical Analysis}

\subsection{An Overview of Relevant Literature}

We analyzed the relationship between the NPL ratio and macroeconomic variables as a source of systemic risk, in order to assess the banking sector's vulnerability to bad-loan performance on a macroeconomic level. The empirical findings presented in the literature (below) are an important source of the hypothesis, especially when it comes to the responsiveness of the NPL ratio on macro factors.

QUAGLIARIELlo (2003) presented a regression between the evolution of NPL ratio as the dependent variable and a set of explanatory variables: real GDP growth rate, the growth of real gross fixed investments and consumption, changes in the unemployment rate, the consumer price index (CPI), the real exchange rate and the M2 growth rate. BABOUČEK and JANČAR (2005) investigated economic developments by unemployment, GDP growth, exports, imports, appreciation, CPI and credit growth, as indicators of NPL ratio performance. HogGarTH, Logan and Zicchino (2005) investigated the link between loan write-offs and output gaps, retail prices, real estate prices, the nominal short-term interest rate and the real exchange rate. С̆ıнÁк et al. (2007) compared system-focused stress testing methods and discussed the issues related to the design of stress tests for the Czech banking system. ЈакUві́к (2007) employed the regression method for NPL inflow estimation using real GDP, real effective exchange rates, the CPI, the loan to GDP ratio, unemployment, and real interest rates as explanatory variables. 
Theoretical background. The economic literature often differentiates between demand factors (such as economic convergence, wealth accumulation, interest rates, inflation, gross domestic product, purchasing power parity etc.) and supply factors (the liberalization of the banking sector, financial deepening etc.) determining sustainable credit growth and a sustainable loan asset ratio (SIRTAINE and SKamnelos, 2007). First, the majority of studies have confirmed that GDP/ (net) export/gross fixed capital formation/employment is a major challenge to loan portfolio quality and the dynamics of the NPL have been proven to be procyclical with respect to economic growth. Periods of economic growth and strong demand for a country's exports have a positive effect on the domestic corporate and household sectors (Borio et al., 2001). ${ }^{1}$ Second, the empirical record associated with an explicit analysis of the exchange rate to NPL relationship is mixed, partly as a result of economies' different degrees of foreign trade openness, as well as with dissimilar (foreign currency) debt exposure in individual sectors. The worsening of banking sector mismatches and the NPL ratio can occur when borrowers borrow in foreign currency (or their loans are nominated in foreign currency) and pay back credit in domestic currency - due to the domestic currency depreciation that threatens the NPL performance and increases debt burdens (EDWARDS, 2001). On the other hand, the appreciation of the real exchange rate (as the result of export growth or the Balassa-Samuelson effect) can contribute to the build-up of a crisis through shifts in international competitiveness coupled with terms of trade deterioration and with the direct implications on loan performance. This can be seen in the fact that bank lending surveys show that loans granted to enterprises are partly hedged by their export proceeds (KAMINSKY and REINHART, 1999).

Third, low bank capitalization (and a low deposit to loan ratio) often lead to the adoption of imprudent lending strategies with direct implications for banks' loan portfolios. These tend to be heavily skewed towards high risk projects (JAPPelli and Pagano, 1994; Lardy, 1999). Applying soft budget constraints, prevalent in many transition countries for providing credit to enterprises or households, may lead to considerable losses in the economy when investments turn out to be counterproductive (BERGLÖF and Roland, 1995) or when the household's liabilities/income ratio is extremely high (Kiss et al., 2006). Higher debt burdens and couterproductive investments can increase the NPL ratio (SIRTAINE and Skamnelos, 2007).

1 Large current account deficits are typical for emerging markets and do not pose a problem as long as they are caused by imports of capital goods, and, if future export growth is strong enough to reimburse foreign debt (KBC AM, 2008; Calvo and Mendoza, 2000). 
Fourthly, the share of banks' loans to the private sector in total banking assets is considered as a proxy of risk taken by the banks (D'Avack and LeVASSEUR, 2007). The loan-assets ratio is positively correlated with banking problems and (in)solvency is a result of long-term bank mismanagement (MäNNASsOO, 2005). Fifthly, the deposits of the private sector as a share of loans to the private sector is used as a rough measure of the profitability of the deposit money or as a proxy for national savings with banks as a rough measure of banking sector reserves (CÂNDIDA, 2009).

\subsection{The Banking Sector in the Macro Environment of the Baltic States}

Due to the fact that less developed economies required investment levels that exceeded domestic savings, the NMS financed a part of their investment through foreign direct investment (FDI) while the huge current account deficits were financed by a steady increase in the net-inflow of FDI, net portfolio investment and foreign currency loans (KBC AM, 2007). The positive impact of FDI and the import of capital goods on economic growth is visible in the diversification of the foreign trade structure, the increase of labour productivity and the improvement of competitiveness in the export industries (BRANDMEIER, 2006, pp.396-400; HAVLIK, 2003), an improvement in the market structure and high growth rates. ${ }^{2}$ Economic growth has been high and widespread: domestic demand, boosted by a foreign-financed boom in bank lending, plummeting unemployment, real wage growth on the back of productivity gains, and export growth, have all contributed to GDP growth after EU accession.

The catching-up process in the New Member States (NMSs) - combined with the general banking sectors' pro-cyclicality - has reinforced credit growth around the EU accession area. Nominal convergence and the lowering of interest rates have also increased demand for leveraging amongst companies and boosted private consumption (BrzozA-Brzezina, 2005). Bank credit has remained an important source of financing: both for investment and consumption. Credit growth in the NMSs has been largely foreign-funded and loans to the private sector have been growing at a rapid pace in the period from 2002-2007.

2 The productivity increases in the tradeable sector during the 1990s induced significant effects with regard to the overall inflationary differences between the NMSs and their main Western trading partners, owing to the Balassa-Samuelson effect, which caused the NMSs' currencies to appreciate in real terms (ChMielewski, 2003; Breuss, 2003). 


\subsubsection{Macro Environment}

The Baltic States conduct a great deal of trade with western, central and eastern Europe. The impact of the Russian crisis in 1998 on these economies brought the differing pace of structural adjustment back into focus but did not reverse the trend. After the Russian crisis, favorable economic development and approaching EU membership increased investments and the amount of credit started to grow (ÅDAHL, 2006).

After EU accession, the Baltics witnessed the recovery of EU economies. The positive externalities of accession to the EU contributed to export growth between 2002 and 2007. Low interest rates, an ongoing credit boom, gains in productivity, the growth of private consumption, fixed capital formation as a major driving force of GDP growth in the Baltics, a higher capacity to absorb EU investment grants and strong external demand have caused relatively high GDP growth rates.

The credit-fuelled domestic demand boom has, moreover, translated into upward price pressures on goods and labour markets, leading to higher inflation. ${ }^{3}$ In the Baltics, it is imports in consumer goods, rather than investment goods, that have inflated import growth in recent years (Table 1). An unabated consumption-led high import propensity has been coupled with moderate export growth due to a loss of competitiveness as a result of rising unit labour. A wage price-spiral, a tight labour market, an unabated credit boom, an emerging realestate bubble, a skyrocketing current account deficit and rapidly rising external debt levels pointed to a potential overheating of the economy after 2006 (KBC AM, 2008).

In the Baltics, signals of economic overheating with a medium-term risk of a hard landing were already evident in 2007. The deceleration of economic growth in the second half of 2008 was mostly due to a supply side shock and the unwinding of the boom in the EU economies in 2008. Looking at the structure of output growth, increasing domestic demand also played a prominent role, since net exports were negatively affected by sluggish economic activity in Europe (KBC AM, 2008). Structural dependence on external financing - which is in part a by-product of the effect of low levels of internal savings - have led to large current account deficits and financial instability.

3 Substantial progress has been made in reducing inflation after 1999 but later, inflation reaccelerated again due to indirect taxes and administered prices, higher food prices and the impact of increasing fuel prices as well. 


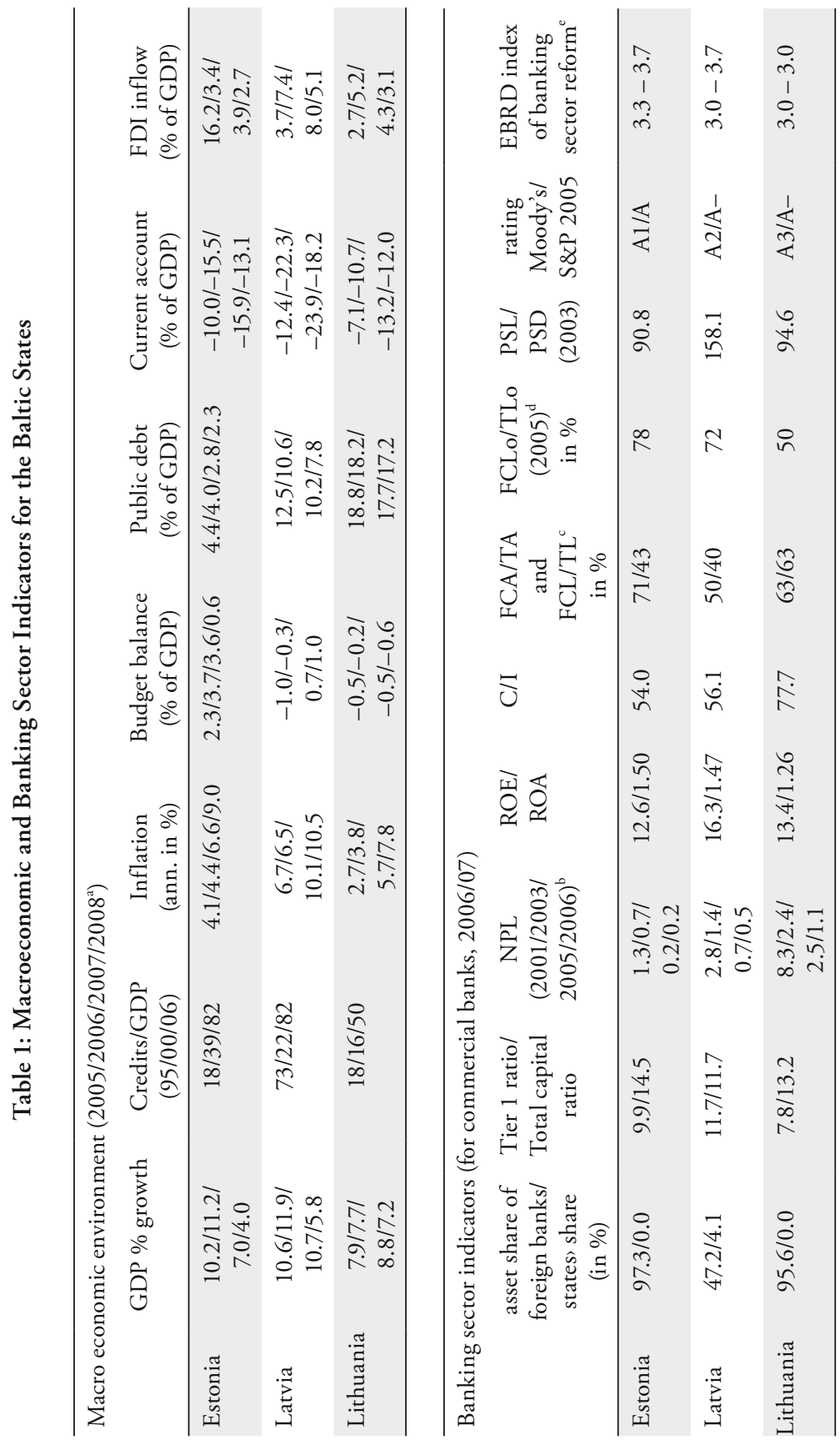




\section{Notes to Table 1}

a Exchange rate regime: ERM II since June 2004 in Estonia and Lithuania; and since May 2005 in Latvia.

b Portfolio quality and loan classification categories: Estonia - standard, watch, doubtful, uncertain, loss; Latvia and Lithuania - standard, watch, substandard, doubtful, loss. Substandard loans are 91 to 180 days past due (and require provisioning between 15 and 40), doubtful loans are 181 to 365 days past due (and require provisioning between 40 and 99) and losses are not repayed (requiring 100\% provisioning). In Estonia, loans overdue for 150 plus days have to be written off in Estonia. In Latvia, although the substandard classification covers loans 31-90 days overdue and provisioning levels are 10/30/60/100 percent, respectively.

c FCA/TA: foreign currency assets as a $\%$ of total assets; and FCL/TL: foreign currency liabilities as a $\%$ of total liabilities.

d FCLo/TLo: foreign currency loans in total loans; and PSL/PSD: private sector loans in private sector deposits.

e The ERBD indicators of banking sector reform are measured on a scale of 1 to 4+ (for 1997 and 2003): score 2: established internal currency convertibility, significant liberalised interest rates and credit allocation; score 3: achieved substantial progress in establishing prudential regulation and supervision framework; score 4: level of reform approximates the BIS institutional standards.

Source: IMF (2007, 2008), ECB (2006), BACA (2008), KBC AM (2008).

Significant amounts of FDI have been tied to the banking sector and the nontradable sector (like the real estate business) which are closely tied to the availability of bank finances. This differentiates the Baltics from central Europe, where most capital inflows are in the form of FDI into the tradable sector.

\subsubsection{The Banking Sector}

The rapid privatization of state-owned companies, and improvements in legal infrastructure, contributed to the development of the banking sector in the Baltic States. While the Estonian and Lithuanian banking sector became truly consolidated, Latvia remained the exception, with a number of smaller niche banks oriented towards the Russian market, attracting in particular non-resident deposits (Eesti Pank, 2006). Estonia had privatized their last remaining large stateowned banks into foreign hands. In Latvia, the large amount of banks is partly explained by the fact that ten of the banks deal primarily with nonresident transactions - meaning investing Russian money in Western Europe. In 1998, Latvian banks suffered relatively large losses due to the Russian crises (Korvu, 2002). For many Latvian banks, receiving deposits from the CIS and reinvesting them in Western Europe is an important business activity. The Lithuanian banking 
sector is considerably smaller. Its effectiveness has been lower than in Estonia or Latvia due to state ownership, which lasted longer in Lithuania, and due to the fact that the banks were too risk-averse and small- and medium-sized enterprises suffered from insufficient financing.

Despite the fact that lending grew rapidly in the period from 2002 to 2007, banks in the Baltics have recently maintained adequate solvency buffers. They also identified consolidation, the adaptation of organizational structures and regulatory incentives, as significant drivers of change (ÅDAHL, 2006). An analysis of financial health EBRD indicators confirms that generally, capital adequacy in the banking sector has been sufficient (Table 1), banks enjoy adequate profitability (profits were also supported by continued cost-containment) and banks have benefited from enhanced asset quality (which has allowed for reduced provisioning).

\subsubsection{Lending in the Banking Sector}

Already in the aftermath of the Russian crisis at the end of the 90s, Estonia and Latvia experienced very rapid loan growth between 2000-2002, while Lithuania lagged somewhat behind. Credit growth picked-up in Estonia and Latvia in the second half of the 90s, while in Lithuania, the credit to GDP ratio has been increasing slightly since 2001. Estonia and Latvia recorded a marked credit ratio growth until 2004, while Lithuania boosted its ratio in 2002. By the end of 2006 , Estonia and Latvia were leading with a roughly $85 \%$ private credit to GDP ratio, followed by Lithuania with a ratio well over 50\%. From 1999-2002, more than half of all loans were granted in foreign currencies and the majority in euros (Table 1). The major share of foreign loans to the private sector consisted of housing loans, which increased remarkably between 1999 and 2002 (KBC AM, 2008).

The acceleration in domestic lending - in particular to households - was fuelled by strongly increasing foreign liabilities (e.g., SopanHa, 2006), while the corporate sector gained better access to alternative financing sources in the Baltics. Many Baltic corporations are likely to find financing elsewhere: either from foreign investors or in European financial markets. Credit growth to the corporate sector lagged behind loans to households, which can be partly explained by the fact that an important share of investment by the non-financial corporate sector was financed by retained earnings, inter-company loans and foreign capital, including credits from banks in other countries and FDI in the period from 2002 to 2006 . 
Figure 1: The NPL Ratio Dynamics in the Baltic States

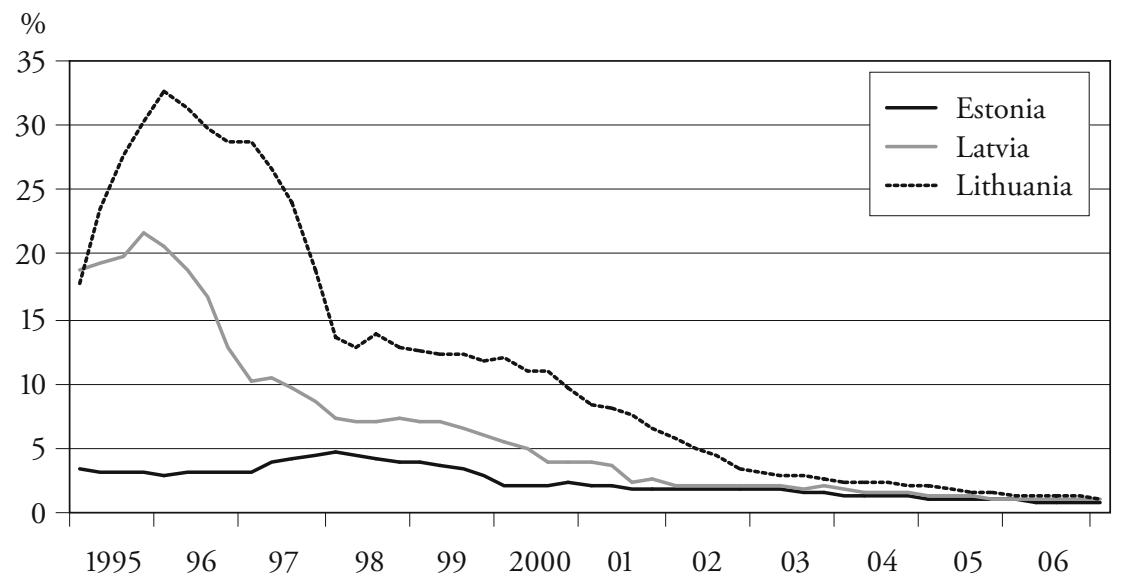

Source: EIPF and BACA (2008).

\subsubsection{Non-Performing Loans}

The transition economies shared a common problem: their banking sectors in the early 1990s were characterized by a relatively small number of large, state-owned institutions that had become burdened by large volumes of non-performing loans. We can point to two reasons for this: first, these countries had to deal with the issue of a large amount of inherited NPL from the past, and second, new NPL's mounted up in the balance sheets of commercial banks due to a lack of experience, government intervention, inappropriate incentives for bank management and poorly designed privatization methods.

In the Baltic states, non-performing loans, dating back to government intervention in state-owned banks and companies in the early 90s (TANG et al., 2000), have been fully written off in recent years. Estonia and Latvia relied on a decentralized model, injecting capital into banks they considered viable and suitable for further privatization, while leaving it to the banks themselves to deal with their bad loans. Lithuania chose a centralized approach and set up a central agency to clean up the bad loans of selected banks and provide banks with government assets for recapitalization. To this effect, the government issued special bonds and transferred cash from the budget (KrzaK, 1997). Since the Russian crisis, non-performing loans have been reduced by half. Supervisory and regulatory 
authorities have proven their mettle in forcing the pace of mergers during the crisis and thereafter rapidly improving supervision (Table 1 ).

\subsubsection{Trends in the Baltics Before Overheating}

In Estonia, GDP growth after 2005 was favourable especially due to favourable developments in the service sector and export growth. Export growth improved economic conditions in Estonia from 1998 to 2007, most likely due to strong productivity growth and increasingly diversified export and import structures that reduced vulnerability in terms of trade deterioration (export growth mainly exceeded import growth in Estonia in the period from 1999 to 2006). After 2004, domestic savings in banks (=deposits) started to augment, which is explainable by the substantially increased income of households and enterprises. But increasing available deposits (and liquidity) with banks did not contribute to NPL ratio deterioration.

Since 2000, Latvia has seen a rapid growth in investments, which encouraged the modernization of production and the introduction of new technologies. In Latvia, the investment to GDP ratio might have risen to maintain strong economic growth, and a healthy banking sector has helped allocate savings towards the most productive investments. Rapid credit growth appears to have been contained by high domestic savings (and deposit accumulation) in Latvia after 2000. On the other hand, the in-flow of foreign capital contributed to a significant growth in liquidity, and surplus liquidity created an additional supply of loans. The current account deficits, strong domestic demand (only partially financed by FDI and net portfolio investments) and productivity adjusted wage growth, relative to trading partners, have highlighted the need for demand restraint to improve the saving-investment balance and slow down the private sector's debt accumulation after 2006.

In Lithuania, economic growth was stimulated by the expanding internal market after the accession to the EU and favourable export conditions, as well as rising household incomes since 2001, bringing economic growth to the general population. After 2004, the decrease of personal income taxes positively affected private savings. In the beginning of 2008, the current account deficit was higher (despite the strong pace of exports) than in the same period in 2007, because FDI and cross-border financing started showing signs of weakness. Flagging economic growth would likely be expected to trigger an adjustment in the current account deficit in Lithuania. 


\subsection{Empirical Analysis: Data Specification, Methodology, Empirical Results and Discussion}

We analyzed the relationship between the NPL ratio and macroeconomic/banking sector variables as a source of systemic risk in order to assess the banking sector's vulnerability to bad-loan performance on a macroeconomic level.

\subsubsection{Data Specification}

Based on the studies of determinants behind the NPL ratio, we constructed a data set of explanatory variables that are usually employed in models. The NPL variable is specified as the share of all nominal loans that are at least 90 days overdue. It is important to note, however, that cross-country variations in asset quality indicators (IMF, 2008) can also be explained by differences in loan classification rules (see notes, Table 1). ${ }^{4}$ The usual definition is that NPLs are defined as loans that are more than 90 days past due, as has been used in our case.

Some authors (see, for example, Јакиві́к 2007a), emphasize the better performance of NPL inflow variables in empirical estimates. The NPL ratio could be problematic to use, where outflow is given by one-off NPL write-offs. This ratio can be driven by purely administrative measures. So, for example, in the New EU Member States, a significant portion of defaulted loans were removed from banks and substituted with government bonds. Since we could not provide the NPL inflow time series, ${ }^{5}$ we had to rely on the use of an NPL series as nominal loans that are at least 90 days overdue. The NPL (in bn of domestic currency and deflated by the consumer price index) as the share of total loans to the private sector (in bn of domestic currency and deflated by the consumer price index) was utilised for the dependent variable in our analysis.

Originally, the following time series for economic activities were utilised: the (net) export of goods and services (in bn of domestic currency deflated by retail price index), gross fixed capital formation in the non-financial sector (in bn of domestic currency deflated by retail price index), gross domestic product (in bn of domestic currency deflated by retail price index) and standardized employment.

4 National practices differ on whether ex-post (evidence from past behavior, such as 90-day nonpayment of interest/principal) or ex-ante information (assess future losses by considering forward-looking information) should be used to assess loan classifications (IMF, 2008).

5 The data on NPL inflow can be estimated as the ratio between non-payed interest and interest. The second possibility is the recovery rate dynamics and the loan loss reserves dynamics that could be used as a proxy for the estimation of NPL inflows and outflow dynamics (see BOLE, 2007). 
Furthermore, we used the real effective exchange rate in an individual country, expressed as the weighted average of a country's currency relative to a basket of other major currencies (measured as a foreign price for domestic currency) and adjusted for the effects of inflation as an explanatory variable (EIPF, 2008). We also used: bank loans to the private sector (i.e. loans to households and corporations, as obtained from banks in the country, in bn of domestic currency deflated by the consumer price index) as a share of total banking assets (in bn of domestic currency deflated by consumer price index), considering this variable as a proxy of risk taken by the banks; and the deposits of the private sector (in bn of domestic currency deflated by consumer price index) as a share of loans (expressed in bn domestic currency deflated by consumer price index), as a rough measure of the profitability of the deposit money. All the nominal variables (expressed in national currencies) were corrected by an individual country's retail price index or consumer price index (the last quarter of 2007 as the base) and converted into EUR by using the exchange rate of the last quarter of 2007 (Table 3).

We relied on the internal database of the BACA (2008), EIPF (2008) and the databases of central banks in individual countries. The quarterly time series was used for the period from the first quarter of 1998 to the last quarter of 2007, in order to explain the NPL ratio in the Baltic States.

\subsubsection{Methodology}

The methods used in different estimations, which look for empirical evidence of a relationship between financial stability, asset quality indicators and macroeconomic variables are, primarily: co-integration analysis, correlations, crosscountry regressions and panel regressions (BECK and KATZ, 1995). According to the relatively short time series and similarities between the analyzed economies, we decided to use panel regression ("cross section weights") (Hsiao, 2003), and obtain more information on the analyzed parameters (WOOLDRIDGe, 2002). According to Temple (1999), this method allows one to control for omitted variables that are persistent over time and, by including lags of regressors, may alleviate measurement errors and endogeneity bias (see also Maddala et al., 1996). The advantage of the applied method is that it lowers co-linearity between explanatory variables (DAVIDSON and MACKInNON, 1993) as well as dismisses heterogenous effects (WESTERn, 1998). We analyzed the model with permanent effects, which controls the impact of neglected and changing variables among observed units that remain constant within a time period (STOCK and WATSON, 2003).

Moffatt and Salies (2003) have demonstrated that logarithmic approximation is only accurate if the rates of change in variables are reasonably small. 
Since the dynamics of the NPL ratio is sometimes large (producing a significant downward bias in the simulation) all the time series were transformed into the difference of the growth rates in the original time series (measured in percentage points). After deriving the transformed time series, the stationarity of all the selected time series was obtained at a $1 \%$ significance level (DiCKEY and Fuller, 1979) and then proven by the ADF-Fischer Test (Esaka, 2003, Appendix, Table A). ${ }^{6}$ The lag length selection in the specified model was based on Schwarz information criterion. Variables (credit/asset ratio, deposit/loan ratio and employment) were seasonally adjusted by the X-12-ARIMA method.

Using quarterly data, we contributed to the existing empirical evidence of the impact of macroeconomic environment on NPL ratio dynamics in the following way: we used panel estimates to explain NPL ratio growth by introducing macroeconomic and banking sector variables. ${ }^{7}$ Using fixed effects within the estimation, we assumed a slope common to each of the countries $\left(b_{i}\right)$, while intercepts varied across each of the countries $\left(c_{i}\right)$ (BECK and KATZ, 2004). The fixed effects were included to account for possible unobserved heterogeneity across nations. ${ }^{8}$ All the calculations were performed by Eviews 6.0. We estimated the following equation:

$$
\begin{aligned}
& \Delta \mathrm{NPL}_{t}=c+b_{1} \cdot \Delta\left(\text { credit } / \text { asset }_{t-n}+b_{2} \cdot \Delta \text { invest }_{t-n}\right. \\
& +b_{3} \cdot \Delta \text { netexp }_{t-n}+b_{4} \cdot \Delta \text { reeffexch }_{t-n} \\
& +b_{5} \cdot \Delta(\text { deposit/loan })_{t-n}+b_{6} \cdot \Delta \text { employ }_{t-n}+\varepsilon_{t}
\end{aligned}
$$

Symbols:

$-\Delta()$ : the difference in growth rate, as measured in percentage points,

- NPL: the share of non-performing loans to total bank loans,

- creditlasset: the ratio between bank credits to the private sector and total banking assets,

- invest: gross fixed capital formation, as a share of GDP,

- netexp: the net export of goods and services,

6 Variables are cointegrated on different levels and there is no long-run equilibrium relationship between the variables.

7 Q-Statistics (Appendix, Table B) were employed to check auto-correlation in the residuals. We accepted the hypothesis of no auto-correlation in residuals - with high probabilities and low Q-statistics (Iwaisako, 2004).

8 Our results (see, Table 2 ) reject the $H_{0}$ hypothesis $\left(H_{0}=\right.$ the fixed effects are all equal to each other) and we accepted the fixed effects in our panel regression model. According to the results of the Cross-section F-test, the system responds well within the fixed-effect estimations in our model. 
- reffexch: the real effective exchange rate,

- deposit/loan: deposits of the private sector as a share of loans,

- employ: employment rate,

$-\varepsilon_{t}:$ error term.

\subsubsection{Empirical Results and Discussion}

The obtained results confirmed the influence of the chosen explanatory variables on the dynamics of the NPL ratio. As expected, we found evidence of a positive influence of the credit/asset ratio (with a coefficient of 0.058 ) and evidence of negative effects by the deposit/loan ratio (with a coefficient of -0.060). The theory of procyclicality between net exports and the NPL ratio, as well as procyclicality between gross fixed capital formation and the NPL ratio was proven with regression coefficients of -0.029 and -0.030 . The increased economic activity improved the loan portfolio quality of the banking sector. Appreciation of the real exchange rate decreased NPL ratio growth by -0.027 percentage points by one percentage point real effective exchange rate appreciation, while employment decreased the NPL ratio growth by -0.063 percentage points.

Simultaneously, using the values obtained by the Cross-section F-tests (Table 2), we can confirm that the common slopes (within the Baltic States) are clear signs of integration, since NPL growth rates have similar reactions to the behaviour of the chosen explanatory variables. Under the conditions of increasing competition, the macroeconomic conditions and banking sector performance have contributed in a similar way to NPL ratio growth. Nevertheless, each country has a different intercept - that is, it had a specific initial condition (Estonia -0.073916 , Latvia -0.0221 and Lithuania -0.03652 ), which is consistent with the fact that the banking sector of these countries have faced different consequences, while adapting to new conditions during the EU integration process.

High credit growth rates were confirmed for the NMSs by STAVRaKeVA (2006) due to financial liberalization, followed by boom-bust cycles in bank lending, economic activity and asset prices (especially real estate). The inflow of foreign capital contributed to a significant growth in liquidity and created an additional supply of loans. Excess credit growth to households, which leads to increasing consumption and causes a deterioration in external accounts, can threaten the stability of the banking sector due to the fact that credit-boom-driven deficits are often financed through short-term external debt creation. Large deficits are typical for emerging markets and do not pose a problem as long as they are caused by the importing of capital goods and if future export growth is strong enough to reimburse foreign debt. 
Table 2: Panel Regression Results for the Baltic States

Dependent Variable: $\Delta(\mathrm{NPL})$

Sample: 1998:1- 2007:4

\begin{tabular}{|c|c|c|c|c|}
\hline Variable & Coefficient & Std. Error & t-Statistic & Prob. \\
\hline$c$ & -0.045405 & 0.005692 & -7.976848 & 0.0000 \\
\hline$\Delta(\text { credit/ asset })_{t-8}$ & 0.057665 & 0.028185 & 2.045983 & 0.0037 \\
\hline$\Delta$ invest $_{t-8}$ & -0.029525 & 0.011821 & -2.497666 & 0.0044 \\
\hline$\Delta$ netexp $_{t-6}$ & -0.029496 & 0.012550 & -2.350157 & 0.0010 \\
\hline$\Delta r e f f e x c h t_{t-6)}$ & -0.027477 & 0.011416 & -2.406820 & 0.0082 \\
\hline$\Delta{\text { deposit/loan })_{t-7}}$ & -0.059375 & 0.018538 & -3.202866 & 0.0019 \\
\hline$\Delta e m p l o y_{t-1}$ & -0.063091 & 0.026945 & -2.341482 & 0.0015 \\
\hline \multicolumn{2}{|l|}{ Fixed Effects (Cross) } & & & \\
\hline Estonia & -0.028511 & & & \\
\hline Latvia & 0.023305 & & & \\
\hline Lithuania & 0.008885 & & & \\
\hline \multicolumn{2}{|c|}{ Cross-section fixed (dummy variables) } & & & \\
\hline \multicolumn{2}{|l|}{ Weighted Statistics } & & & \\
\hline Adjusted R-squared & 0.304527 & & & \\
\hline S.E. of regression & 0.080217 & & & \\
\hline F-statistic & 6.254451 & & & \\
\hline \multicolumn{5}{|c|}{ Redundant Fixed Effects Test } \\
\hline Effects Test & Statistic & d.f. & & Prob. \\
\hline Cross-section F & 3.341800 & $(2,88)$ & & 0.0399 \\
\hline
\end{tabular}

Symbols: $\Delta$ : denotes the difference in growth rates of the variables, NPL: the share of non-performing loans to total bank loans, credit/asset: the ratio between bank credits to private sector to banking sector assets, invest: gross fixed capital formation (in non-financial sector) as share of GDP, netexp: net export of goods and services, reffexch: real effective exchange rate in an individual country, deposit/loan: deposits of the private sector as a share of total loans to the private sector, employ: standardized employment rate.

* The time lag of an individual coefficient is given in subscripts. 
The inflow of foreign capital contributed to a significant growth in liquidity and the surplus liquidity created an additional supply of loans. The real exchange rate appreciation has not proven to deteriorate NPL ratio growth. BReuss (2003, 25) saw the appreciation of the real exchange rates as a result of productivity gains in the tradable sector and as a "natural phenomena in catching-up countries," which did not erode export competitiveness because higher investments led to a rise in external competitiveness and higher exports (BRANDMEIER, 2006), expanding the capability of a country to service foreign debt (Wu, 2004). Despite good foreign direct investment coverage and the recovery of export growth, the sustainability of the external imbalance is, in the medium term, an issue of concern for the banking sectors. A slowdown in economic activity and a higher balance of payment deficit is also likely to deteriorate NPL ratio growth in the Baltic States, with negative repercussions on debt repayment. The slowdown in economic activity is likely expected to accelerate the NPL ratio growth in the NMSs (Égert, Backé and Žumer 2006; Kiss et al., 2006).

\section{Conclusion}

In this study, we demonstrated that the credit/asset ratio contributed to an increase in the dynamics of the NPL ratio within the observed economies. Our estimates for the Baltic States therefore support the hypothesis that the growth of credit might harm banking performance (most probably due to soft-loan constraints, ample liquidity in the banking sector - as the result of capital inflows; and overheating of economies). Our results do support the hypothesis that the appreciation of a real effective exchange rate could contribute to an improvement in loan portfolio quality, due to a high share of loans nominated in foreign currency and productivity increases. The results also imply that gross fixed capital formation in the selected economies contributed to an increase in economic activity and lower NPL ratios. Since we confirmed that the boost in the net export of these economies improved the NPL ratio, the eventual weakening of growth in export-oriented industries could lead to economic contraction, with a direct impact on the sustainability of banking-sector results in these countries.

We can also state that strong economic growth and a decelerating non-performing-loan ratio, within the context of the procyclicality theory, can be interpreted as a signal for economic overheating and therefore as a potential threat to banking sector performance. 


\section{Appendix}

Table A: Results of the ADF - Fisher Test*

\begin{tabular}{lll}
\hline & Statistic & Prob. \\
\hline$\Delta$ NPL & 98.8166 & 0.0000 \\
$\Delta($ credit/asset $)$ & 76.0887 & 0.0000 \\
$\Delta$ invest & 77.8095 & 0.0000 \\
$\Delta$ netexp $)$ & 51.4232 & 0.0000 \\
$\Delta$ reffexch & 42.9670 & 0.0000 \\
$\Delta($ deposit/loan $)$ & 80.7006 & 0.0000 \\
$\Delta$ employ & 74.6714 & 0.0000 \\
\hline
\end{tabular}

*Probabilities for ADF - Fisher Test are computed using the asymptotic Chi-square distribution.

Table B: Autocorrelation of the Residuals (Sample: 1998:1-2007:4)

\begin{tabular}{|c|c|c|c|c|c|c|c|}
\hline \multicolumn{2}{|c|}{ Autocorrelation } & \multicolumn{2}{|l|}{ Partial Correlation } & $\mathrm{AC}$ & \multirow{2}{*}{$\begin{array}{c}\text { PAC } \\
-0.099\end{array}$} & \multirow{2}{*}{$\frac{\text { Q-Stat }}{5.9441}$} & \multirow{2}{*}{$\frac{\text { Prob }}{0.312}$} \\
\hline 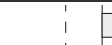 & $\square$ & $\square$ & 1 & 0.003 & & & \\
\hline 1 & 1 & $\square$ & 2 & -0.025 & -0.025 & 5.9725 & 0.426 \\
\hline$\square$ & 1 & - & 3 & -0.116 & -0.082 & 6.5917 & 0.473 \\
\hline 1 & 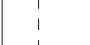 & 1 & 4 & -0.081 & -0.040 & 5.9060 & 0.547 \\
\hline 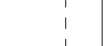 & 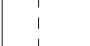 & 4 & 5 & -0.057 & -0.046 & 7.0675 & 0.630 \\
\hline 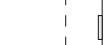 & 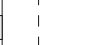 & 1 & 6 & -0.015 & -0.028 & 7.0789 & 0.718 \\
\hline 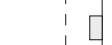 & 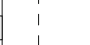 & 1 & 7 & -0.008 & -0.009 & 7.0819 & 0.792 \\
\hline 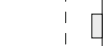 & 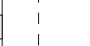 & 1 & 8 & -0.022 & -0.046 & 7.1102 & 0.850 \\
\hline 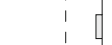 & 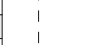 & 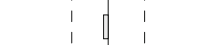 & 9 & -0.149 & -0.169 & 8.4197 & 0.815 \\
\hline i & i & 1 & 10 & -0.007 & 0.106 & 8.4229 & 0.866 \\
\hline 1 & i & i & 11 & 0.040 & -0.048 & 8.5246 & 0.901 \\
\hline 1 & i & 1 & 12 & 0.103 & 0.037 & 9.2419 & 0.903 \\
\hline$\square$ & 1 & $\square$ & 13 & 0.066 & 0.063 & 9.5551 & 0.921 \\
\hline 1 & i & $\begin{array}{l}1 \\
1\end{array}$ & 14 & -0.027 & -0.106 & 9.6118 & 0.944 \\
\hline 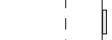 & 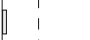 & 1 & 15 & 0.043 & 0.141 & 9.7598 & 0.959 \\
\hline 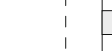 & 0 & $\begin{array}{lll}1 & 0 \\
1 & 0\end{array}$ & 16 & 0.046 & -0.053 & 9.9403 & 0.969 \\
\hline
\end{tabular}




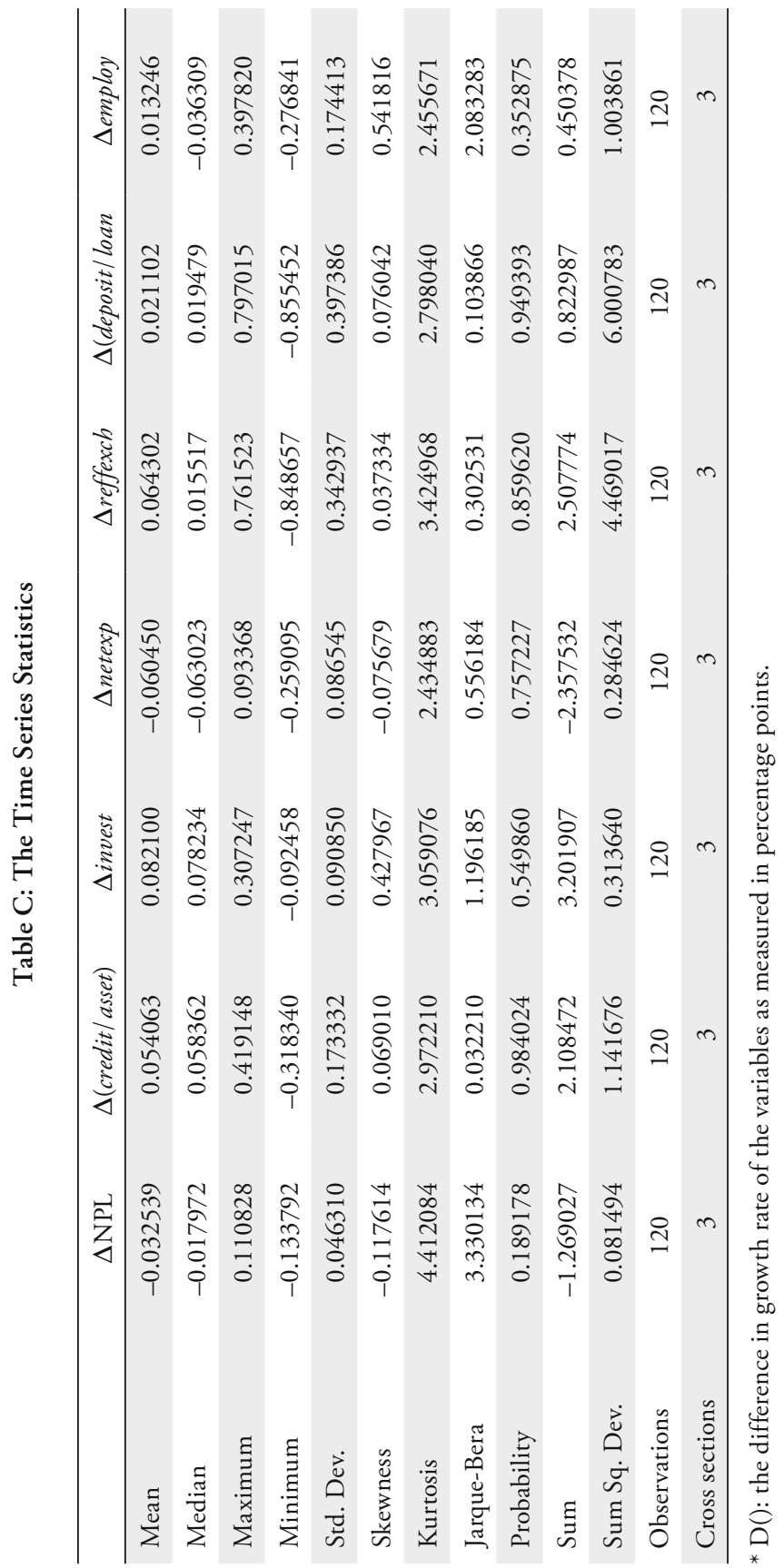




\section{References}

Ådahl, Martin (2006), "Banking in the Baltics - The Development of the Banking Systems of Estonia, Latvia and Lithuania since Independence: The Internationalization of Baltic banking 1998-2002", Vienna, Österreichische National Bank, http://www.oenb.at/en/geldp_volksw/zentral_osteuropa/banksecfmstab/banking_sector_and_financialstability.jsp, 3 September 2006.

BabouČeK, Ivan, and Martin Jančar (2005), "A VAR Analysis of the Effects to Macroeconomic Shocks to the Quality of the Aggregate Loan Portfolio of the Czech Banking Sector", working paper series no. 1, Prague, the Czech National Bank.

BACA (2008), "Analysis and research in the CEE countries", http://www.ba-ca. com/en/open.html?opencf=/en/18539.html, 14 February 2007.

Beck, Nathaniel, and N. Jonathan Katz (1995), "What to Do (and not to Do) with Time-Series Cross-Section Data", American Political Science Review 89 (3), pp. 634-647.

Beck, Nathaniel, and N. Jonathan Katz (2004), "Random Coefficient Models for Time-Series-Cross-Section Data”, Working Papers, no. 1205, California Institute of Technology, Division of the Humanities and Social Sciences.

Berglöf, Erik, and Gerard Roland (1995), "Bank Restructuring and Soft Budget Constraints in Financial Transition”, in: CEPR, Discussion Papers no. 1250, London, CEPR, http://ideas.repec.org/p/cpr/ceprdp/1250.html, 13 April 2006.

Bole, Velimir (2007), "Basel II for the Bank of Slovenia and the A-Banka", project for the Bank of Slovenia, Introduction of Basel II in Slovenian Banks, aplicative model for Slovenian commercial banks, Ljubljana, EIPF.

Borio, Claudio, Craig Furfine and Philip Lowe (2001), "Procyclicality of the financial system and financial stability: issues and policy options", In Marrying the Macro and Micro-Prudential Dimension of Financial Stability, March, no. 1, pp. 24-31, Bank for International Settlements, http.//www.bis. org, 23 December 2007.

Brandmeier, Michael (2006), "Reasons for real appreciation in Central Europe", in: Discussion Paper no. 55, May, pp. 396-400, Centre for Globalisation and Europeanization of the Economy, http://www.cege.wiso.unigoettingen.de/Dokumente/55_Brandmeier.pdf, 13 June 2006.

Breuss, Fritz (2003), "Balassa-Samuelson Effect in CEEC. Are There Obstacles for Joining the EMU?", in: Working Papers, no. 52, May, Vienna, IEF, 
Institute Vienna, http://www.univ-paris13.fr/CEPN/coudert_5_balassa.pdf, 13 June 2006.

Brzoza-Brzezina, Michal (2005), "Lending booms in the New Member States, Will Euro adoption matter?”, in: Working Paper no. 543, December, Frankfurt, ECB, http://www.ecb.int/pub/pdf/scpwps/ecbwp543.pdf, 15 May 2006.

Calvo, A. Guillermo, and Enrique Mendoza (2000), "Contagion, Globalization and the Volatility of Capital Flows", in: Capital Flows and the Emerging Economies, S. Edwards (ed.). Chicago: University of Chicago Press, pp. 12-43.

CÂndida Ferreira (2009), Bank Sector Performances, Economic Growth and European Integration, Lisboa, Instituto Superior de Economia e Gestão da Universidade Técnica de Lisboa, no. 2. http://www.umar.gov.si/fileadmin/ user_upload/konference/02/09_Ferreira.pdf, 13 January 2009.

Chmielewski, Tomasz (2003), "Is the Balassa-Samuelson Effect a Serious Obstacle for an Accession Country?", in: INFER Studies, Alpen, Dagmar, and Hendrik Luchtmeier (eds), vol. 8, pp. 1-18, Berlin, VWF.

Čimák, Martin, Jaroslav HeŘmánek and Michal Hlaváčer (2007), "New Approaches to the Stress Testing of the Czech Banking Sector", Czech Journal of Economics and Finance, Finance a úvèr 10 (2), pp.41-59.

Davidson, Russell, and G. James MacKinnon (1993), Estimation and Inference in Econometrics, Oxford Univeristy Press.

D'Avack, Francesco, and Sandrine Levasseur (2007), The Determinants of Capital Buffers in CEECs, Paris, OFCE, no. 28, October. Available: [http:// www.ofce.sciences-po.fr/pdf/dtravail/WP2007-28.pdf], (15.1.2009).

Dickey, A. David, and Wayne A. Fuller (1979), "Distribution of the Estimators for Autoregressive Time Series with Unit Root", Journal of American Statistical Association, vol.74 (June), pp. 427-431.

ECB (2006) "Acceding Economies Macro Environment and Banking Sector", in: Occasional Paper, 48 (July), pp. 11-31, Frankfurt, European Central Bank, http://www.ecb.int/ecbop48[1].pdf, 9 September 2006.

Edwards, Sebastian (2001), "Exchange Rate Regime, Capital Flows and Crisis Prevention", NBER and University of California, Los Angeles, http://www. anderson.ucla.edu/faculty/sebastian.edwards/woodstock2.pdf, 24 December 2006.

Eesti Pank (2006), "Banking Sector Stability and Risks", Financial Stability Review, May, pp.44-55, Estonian Central Bank; http://www.eestipank.info/ jump?objId=876910, 3 September 2006. 
Égert, Balázs, Peter Backé and Tina Žumer (2006), "Credit Growth in Central and Eastern Europe: the New (Over-) Shooting Stars?”, ECB working papers, no. 167, October, Frankfurt, ECB.

Esaka, Taro (2003), "Panel Unit Root Tests of Purchasing Power Parity between Japanese Cities, 1960-1998: Disaggregated Price Data", Japan and the World Economy 15 (2), pp. 233-244.

Havlik, Peter (2003), "EU Enlargement: Implications for Growth and Competitiveness", in a study commissioned by the Austrian Federal Ministry for Economy and Labour, August, Vienna, The Vienna Institute for International Economic Studies.

Hoggarth, Glenn, Andrew Logan and Lea Zicchino (2005), "Macro stress tests of UK banks", BIS papers, no. 22, Basel, Bank for International Settlements.

Hsiao, Cheng (2003), Analysis of Panel Data, Kindle edition, Oxford University Press.

IMF (2007), "Global Financial Stability Report - Statistical Appendix", Washington, IMF, http://www.imf.org/external/ns/search.aspx?NewQuery=RoA $\&$ Sort $=$ Score $\&$ Filter_Val=N\&page $=2 \&$ col $=S I T E N G \&$ collection $=\&$ year $=\&$ rcount=50\&swr=0\&LastQuery=\&Lan=eng\&adv=0, 19 August 2006.

IMF (2008), "Compilation Guide to Financial Soundness Indicators, Provisioning and Classification Rules", http://www.imf.org/external/np/sta/fsi/ eng/2004/guide/appendx.pdf, 19 June 2008.

Iwaisako, Tokuo (2004), "Stock Index Autocorrelation and Cross-Autocorrelations of Size-Sorted Portfolios in the Japanese Market", Journal of Financial Economics 3, pp. 281-318.

Jakubík, Peter (2007), "Macroeconomic Environment and Credit Risk", Czech Journal of Economics and Finance, Finance a úvèr, 10 (1), pp. 166-133.

Jakubík, Peter (2007a), "Credit risk and stress testing of the Czech banking sector”, Economic Research and Financial Stability Department, Prague, Czech National Bank.

Jappelli, Tulio, and Marco Pagano (1994), "Savings, Growth and Liquidity Constraints”, Quarterly Journal of Economics 109 (1) February, pp. 93-109.

Kaminsky, Graciela, and M. Carmen Reinhart (1999), "The Twin Crises: The Causes of Banking and Balance of Payments Problems", American Economic Review, 89 (June), pp. 473-500.

KBC AM. (2007), "Baltic States: Caught between a Rock and a Hard Place", Economic Research Notes, 5 (6), annex 11. 
KBC AM. (2008), "Credit growth and housing in Central Europe", http:// www.fxstreet.com/fundamental/analysis-reports/cee-report/2008-04-18.html, 18 June 2008).

Kiss, Gergely, Márton Nagy and Bálasz Vonnak (2006), "Credit Growth in Central and Eastern Europe: Trend, Cycle or Boom?", Magya Nemzeti Bank, Working Papers no. 2006/10.

Koivu, Tuuli (2002), "Banking and Finance in the Baltic Countries", Bank of Finland, Institute for Economies in Transition, BOFIT, no. 11.

KrzaK, MaCiej (1997), "Estonia, Latvia and Lithuania - from Plan to Market Selected Issues", Österreichische Nationalbank: Focus on Transition, no. 2. http://www.oenb.at/en/img/krzak_ftr_297_tcm16-10436.pdf, 16 June 2008.

Lardy, R. Nicholas (1999), "When will China's Financial System meet China's Needs?”, in: Paper prepared for Conference on Policy Reform in China, Center for Research on Economic Development and Policy Reform, CA, November, Stanford, University of Stanford, http://www.brookings.org/ views/papers/lardy/19991118.htm, 13 May 2007.

Maddala, G. S., and Wanhong Hu (1996), "The pooling problem”, In: The econometrics of panel data, ed. L. M'aty'as and P. Sevestre, pp. 307-322, Dordrecht, Kluwer Academic.

Männasoo, Kadri (2005), "Investigating the Early Signals of Banking Vulnerability in Central and East European Emerging Markets", Bank of Estonia: December, working papers series. http://www-1.mtk.ut.ee/varska/2005/I_ Makromaj/Mannasoo.pdf, 13 January 2007.

Moffatt, Peter, and Evens Salies (2003), "A Note of the Modelling of HyperInflation", City University Discussion Paper, no.3, London, City University, http://econwpa.wustl.edu/eps/em/papers/0406/0406002.pdf, 13 August 2007.

Mörttinen, Lenna, Paolo Poloni, Patrick Sandras and Jukka Vesala (2005), "Analysing Banking Sector Conditions: How to Use Macro-Prudential Indicators", ECB, occasional paper, April, no. 26.

Quagliariello, Mario (2003), "Macroeconomics Indicators Useful in Predicting Bank Loan Quality? Evidence from Italy", Rome, Bank of Italy, http:// www-users.york.ac.uk/-mq1 02/mpa_en.pdf, 15 April 2006.

Schinasi, J. Garry (2005), Preserving Financial Stability, Washington, International Monetary Fund, economic issues, no. 36.

Sirtaine, Sophie, and Ilias Kamnelos (2007), "Credit Expansion in Emerging Europe: A Cause for Concern?”, Economic Report World Bank, no. 38499. 
Sopanha, SA (2006), "Capital Markets and Credit Boom in Emerging Market Economies", Financial Stability Review no. 9. Paris, Banque de France.

Stavrakeva, Vania (2006), "Rapid Credit Growth Rates in Transitional Economies with an Emphasis on Bulgaria", ECO 490, http://dspace.nitle.org/bitstream/10090/4169/6/Stavrakeva.pdf, 15 August 2008.

Stock, James, and Mark Watson (2003), Introduction to Econometrics, Chicago: University of Chicago Press.

Tang, Helena, Edda Zoli and Irina Klytchnikova (2000), Banking Crises in Transition Economies: Fiscal Costs and Related Issues, no. 2484, http://ideas. repec.org/p/wbk/wbrwps/2484.html, 19 June 2008.

Temple, Jonathan (1999), "The New Growth Evidence", Journal of Economic Literature, 37 (1), pp. 112-156.

Western, Bruce (1998), "Causal Heterogeneity in Comparative Research: A Bayesian Hierarchical Modelling Approach", American Journal of Political Science, 42 (4), pp. 1233-1259.

Wooldridge, John (2002), Econometric Analysis of Cross Section and Panel Data, Cambridge: The MIT Press.

Wu, Deming (2004), Capital Accumulation and the Balassa-Samuelson Effects: A New Perspective, Stanford University, Department of Economics, http://www.stanford.edu/ demingwu/writing/Capital_Accumulation_and_Balassa_Samuel son_04_11_04.pdf, 13 June 2008.

\section{SUMMARY}

We tested for the significance of macroeconomic variables that condition nonperforming loan (NPL) ratios. The hypothesis of procyclicality between economic activity and improving NPL ratio in the Baltic States was proved.

The increased economic activity improved the NPL ratio. Due to a high share of loans denominated in a foreign currency and the fact of productivity gains in the tradable sector, the appreciation of the real exchange rate contributed to an improvement in NPL ratio.

The procyclicality of banking sector performance and high economic activities growth could be a signal of an economy overheating in the Baltics. 